\title{
RECYCLING OF PINEAPPLE WASTE USING LACTOBACILLUS DELBROECKII TO LACTIC ACID
}

\author{
Abdullah Moch Busairi \\ Department of Chemical Engineering, Faculty of Engineering, Diponegoro University, \\ Phone: (024) 7460058, e.mail: abd_busairi @yahoo.com.
}

\begin{abstract}
Abdullah, in paper recycling of pineapple waste using lactobacillus delbroeckii to lactic acid, explain that The pineapple wastes juice contains mainly sucrose, glucose, fructose and other nutrients. It therefore can potentially be used as carbon source for organic acid fermentation. Recently, lactic acid has been considered to be an important raw material for production of biodegradable lactate polymer. The experiments were carried out in shake flask fermentation using Lactobacillus delbrueckii. Effect of some parameters such as temperature, initial $\mathrm{pH}$, initial substrate concentration, yeast extract concentration and fermentation time to the yield have been studied. The highest yield was $85.65 \%$ achieved at $40{ }^{\circ} \mathrm{C}, \mathrm{pH} 6.00,52.5 \mathrm{~g} / \mathrm{l}$ sugar concentration with $5 \mathrm{~g} / \mathrm{l}$ yeast extract. There was no significant increasing in lactic acid production was observed if supplementation of yeast extract above $10 \%$..
\end{abstract}

Keywords: Lactic acid fermentation, liquid pineapple waste, Lactobacillus delbrueckii

\section{INTRODUCTION}

Food processing operation also uses enormous quantities of water which are consequently discharge as a polluted effluent. The waste are contain high concentration of biodegradable organic material and suspended solid. As a result it has a high BOD and extremes of $\mathrm{pH}$ conditions (Buckle, 1989). . The solid waste from pineapple canning process was estimated about $40-50 \%$ from fresh fruit as pineapple peals and cores. If these wastes discharge to the environment intreated they could cause a serious environment problems. Beside their pollution and hazard aspects in many cases, food processing waste such as pineapple waste might have a potential for recycling to get raw material or for conversion into useful product of higher value added products, or even as raw material for other industries, or for use as food or feed after biological treatment (Kroyer, 1991). This waste contains valuable components which are mainly sucrose, glucose, fructose and other nutrients (Busairi and Mat, 1998; Sasaki et al.1991). An attempt has been made by many researchers to utilise the waste for producing high value added chemicals such as Single Cell Protein (SCP), ethanol, acetic acid, oxalic acid and biomethanation process (Sasaki et al.1991; Bardiya et al.,1996; Vimal and Adsole, 1976). Based on physico-chemical properties of the pineapple waste, it can potentially be used as carbon sources for organic acid fermentation such as lactic acid fermentation.

Lactic acid was chosen as the present product, it is one of the most important organic acids is widely used in the food of industries. Recently, lactic acid has been considered to be an important raw material for production of biodegradable lactide polymer (Goksungur and Guvenc,1997).

The objective of this study was to examine the potential of pineapple waste juice as a carbon source for lactic acid production using Lactobacillus delbrueckii

\section{MATERIALS AND METHODS \\ Substrate}

The substrate used to carry out the fermentation process was pineapple waste juice obtained from Malaysian Cannery of Malaysia Sdn. Bhd. The pretreatment of substrate was described by Lazaro (Lazaro, 1989). .

\section{Strain}

The micro-organism used in this study was Lactobacillus delbrueckii subsp. delbrueckii ATCC 9649 obtained from DSMZ, Germany. The strain was maintained on MRS agar at $4^{\circ} \mathrm{C}$ and transferred to fresh medium every month.

\section{Inoculum Media}

The culture was transferred to liquid MRS medium and than incubated in incubator shaker at $37^{\circ} \mathrm{C}, 150 \mathrm{rpm}$ for 24 hours (Goksungur and Guvenc,1997; Sakamoto and Komagata, 1996).

\section{Fermentation Experiment}

The shake flask fermentation were conducted in a temperature controller shaker. The shake flasks were performed by transferring $5 \mathrm{ml}$ of Inocolum to a $250 \mathrm{ml}$ erlenmeyer flask containing $95 \mathrm{ml}$ of substrate by adding $\mathrm{CaCO}_{3}(3 \% \mathrm{w} / \mathrm{v})$ for $\mathrm{pH}$ control in the shake flask fermentation (Mercier and Yerushalmi, 1992; Vahvaselha, and Linko, 1987)

\section{Chemical Analysis}


The Organic acid content was measured by HPLC (Waters TM 600). A $250 \mathrm{~mm} \mathrm{X} 4.6 \mathrm{~mm}$ ID Spherisob Octyl column (Waters) with UV detector $(210 \mathrm{~nm})$ were used. The eluent used was $0.2 \mathrm{M}$ phosphoric acid at flow rate $0.8 \mathrm{ml}$ per minute and temperature $25{ }^{\circ} \mathrm{C}$. The sugar content was also measured by the same HPLC, using a $300 \mathrm{~mm} \mathrm{X} 4$ mm ID. $\mu$ Bondapak/Carbohydrate column (Waters) with RI detector. The eluent used was a mixture acetonitrile : water (80:20) at flow rate of $2 \mathrm{ml}$ per minute and temperature $25{ }^{\circ} \mathrm{C}$.

\section{RESULTS AND DISCUSSION \\ Effect of Initial pH To The end Product}

The product of lactic acid fermentation was studied at four different initial $\mathrm{pH}$ values of 6.0, 6.5, 7.0 and 7.5. The result of these fermentation also used to express effect of adding $\mathrm{CaCO}_{3}(3 \% \mathrm{w} / \mathrm{v})$ for $\mathrm{pH}$ control in the shake flask. The effect of initial $\mathrm{pH}$ on the yield of lactic acid can be shown in Table 1. However the last $\mathrm{pH}$ value of initial $\mathrm{pH}$ 6.0 and 6.5 is similar but the yield is different, it might be due the microbial growth at initial $\mathrm{pH} 6$ better than 6.5 or concentration of bacteria more higher so the lactic acid production at initial $\mathrm{pH} 6$ higher than $\mathrm{pH} 6.5$ (55.36 and $44.97 \mathrm{~g} / \mathrm{l})$. With increasing initial $\mathrm{pH} 7.0$ to 7.5 during fermentation the last $\mathrm{pH}$ increase from 6.15 to 6.4 and lactic acid production decreased from 44.20 to $36.25 \mathrm{~g} / \mathrm{l}$. This indicated that the adding $\mathrm{CaCO}_{3}(3 \%$ w/v) was effective for control $\mathrm{pH}$ value about 6.0.

Table 1. Effect of Initial $\mathrm{pH}$ at The end Result of Fermentation

\begin{tabular}{cccccc}
\hline $\begin{array}{c}\text { Initial } \\
\mathrm{pH}\end{array}$ & $\begin{array}{c}\text { Lactic } \\
\text { Acid } \\
(\mathrm{g} / \mathrm{l})\end{array}$ & $\begin{array}{c}\text { Yield } \\
(\%)\end{array}$ & $\begin{array}{c}\text { Glucose } \\
\text { Left } \\
(\mathrm{g} / \mathrm{l})\end{array}$ & $\begin{array}{c}\text { Fructose } \\
\text { Left } \\
(\mathrm{g} / \mathrm{l})\end{array}$ & $\begin{array}{c}\text { Last } \\
\mathrm{pH}\end{array}$ \\
\hline 6.0 & 55.36 & 79.80 & 3.26 & 7.70 & 6.02 \\
6.5 & 46.23 & 66.04 & 4.68 & 15.52 & 6.05 \\
7.0 & 44.20 & 63.10 & 5.43 & 17.40 & 6.15 \\
7.5 & 36.25 & 51.78 & 8.81 & 18.84 & 6.40 \\
\hline
\end{tabular}

\section{Effect of Substrate Concentration}

In order to determine the effect of sugar concentration on the final concentration of lactic acid produced, dilute pineapple waste containing $23.3,35,52.5$ and $70 \mathrm{~g} / \mathrm{l}$ of sugar were used. Fermentation was performed in shake flask at $40^{\circ} \mathrm{C}, \mathrm{pH} 6.0,5 \%$ yeast extract, $150 \mathrm{rpm}$ and Inocolum $5 \%$. For control the $\mathrm{pH}$, the substrate must be added calcium carbonate $3 \%(w / v)$. After 144 hours the end of $\mathrm{pH}$ with different concentration of sugar were constant and this indicates that by adding calcium carbonate $3 \%$ to the substrate could control the $\mathrm{pH}$ at 6.00 in fermentation process. The result can be seen in Table 2 .
Table 2. Effect of Substrate Concentration at The end Result of Fermentation

\begin{tabular}{lllll}
\hline $\begin{array}{l}\text { Initial } \\
\begin{array}{l}\text { Sugar } \\
(\mathrm{g} / \mathrm{l})\end{array}\end{array}$ & $\begin{array}{l}\text { Lactic } \\
\text { Acid } \\
(\mathrm{g} / \mathrm{l})\end{array}$ & $\begin{array}{l}\text { Yield } \\
(\%)\end{array}$ & $\begin{array}{l}\text { Glucose } \\
\text { Left }(\mathrm{g} / \mathrm{l})\end{array}$ & $\begin{array}{l}\text { Fructose } \\
\text { Left }(\mathrm{g} / \mathrm{l})\end{array}$ \\
\hline 70.00 & 55.36 & 79.80 & 3.26 & 7.70 \\
52.50 & 44.97 & 85.65 & 2.30 & 3.88 \\
35.00 & 28.94 & 82.60 & 0.68 & 5.83 \\
23.33 & 19.19 & 82.25 & 0.00 & 2.02 \\
\hline
\end{tabular}

The yield increased with increasing of initial sugar concentration, and the yield value were $82.25,82.6,85.65$ and $79.8 \%$. When the initial sugar concentration exceeded $52.5 \mathrm{~g} / \mathrm{l}$, yield values decreased due to inhibition produced by high sugar concentration, a characteristic of a batch culture. The glucose utilisation better than fructose, but both the sugar were not completely utilised exception for level initial sugar concentration 23.3 $\mathrm{g} / \mathrm{l}$. The biomass concentrations were not measured because calcium carbonate in shake flask fermentation was not completely soluble in substrate, so interfered with bacterial density measurement.

\section{Effect of Temperature}

Lactic acid bacteria such are classified as thermophilic or meshopilic. L. delbrueckii is meshopilic bacteria which grow at $17-50{ }^{\circ} \mathrm{C}$ and have optima growth between 20 to $40{ }^{\circ} \mathrm{C}$ (Buchta, 1983). The temperature was studied at $30,35,40$, 45 , and $50{ }^{\circ} \mathrm{C}$ using $70 \mathrm{~g} / \mathrm{l}$ of sugar concentration, 5 $\%$ yeast extract at $\mathrm{pH}$ 6.0. The effect of temperature to the yield can be seen in Table 3. The yield increased with each increase at temperature level of fermentation (30 to $40{ }^{\circ} \mathrm{C}$ ). The lactic acid production decrease above temperature $45^{\circ} \mathrm{C}$, it might be due at this temperature the growth not optima therefore the yield become smaller, and the highest yield at $79.8 \%$, was achieve at $40{ }^{\circ} \mathrm{C}$.

Table 3. Effect of Temperature at The end Result of Fermentation

\begin{tabular}{lllll}
\hline $\begin{array}{l}\text { Temperat } \\
\text { ure } \\
\left({ }^{\circ} \mathrm{C}\right)\end{array}$ & $\begin{array}{l}\text { Lactic } \\
\text { Acid } \\
(\mathrm{g} / \mathrm{l})\end{array}$ & $\begin{array}{l}\text { Yield } \\
(\%)\end{array}$ & $\begin{array}{l}\text { Glucose } \\
\text { Left } \\
(\mathrm{g} / \mathrm{l})\end{array}$ & $\begin{array}{l}\text { Fructose } \\
\text { Left } \\
(\mathrm{g} / \mathrm{l})\end{array}$ \\
\hline 30 & 14.03 & 20.04 & 20.18 & 31.47 \\
35 & 42.90 & 50.47 & 9.35 & 16.43 \\
40 & 55.36 & 79.08 & 3.26 & 7.70 \\
45 & 53.06 & 75.80 & 5.11 & 9.61 \\
50 & 32.71 & 46.71 & 13.64 & 21.89 \\
\hline
\end{tabular}

Among the different nitrogen sources supplemented to the substrate which having the same elemental nitrogen level, yeast extract was the 
best (Hujanen and Linko, 1996; Arasaratnam,et al., 1996).

Yeast extract with different amount was added to pineapple waste juice to obtain the final concentration: 5, 10, 15, 20, and $25 \mathrm{~g} / \mathrm{l}$. All experiment the initial sugar level was kept at $70 \mathrm{~g} / \mathrm{l}$. The effect of different concentration yeast extract to production of lactic acid can be seen in Table 4 .

Table 4. Effect of Addition of Yeast Extract at The end Result of Fermentation

\begin{tabular}{lllll}
\hline $\begin{array}{l}\text { Yeast } \\
\begin{array}{l}\text { Extract } \\
(\mathrm{g} / \mathrm{l})\end{array}\end{array}$ & $\begin{array}{l}\text { Lactic } \\
\text { Acid }(\mathrm{g} / \mathrm{l})\end{array}$ & $\begin{array}{l}\text { Yield } \\
(\%)\end{array}$ & $\begin{array}{l}\text { Glucose } \\
\text { Left } \\
(\mathrm{g} / \mathrm{l})\end{array}$ & $\begin{array}{l}\text { Fructose } \\
\text { Left } \\
(\mathrm{g} / \mathrm{l})\end{array}$ \\
\hline 5 & 55.36 & 79.08 & 3.26 & 7.70 \\
10 & 56.90 & 81.29 & 2.18 & 7.34 \\
15 & 57.49 & 82.14 & 2.04 & 7.66 \\
20 & 57.53 & 82.19 & 2.46 & 7.28 \\
25 & 57.75 & 82.35 & 1.89 & 6.79 \\
\hline
\end{tabular}

When pineapple waste was supplemented with $5 \mathrm{~g} / \mathrm{l}$ of yeast extract the production of lactic acid is $55.36 \mathrm{~g} / \mathrm{l}$, with increasing concentration yeast extract $10 \mathrm{~g} / \mathrm{l}$, the lactic acid production was increased $81.29 \mathrm{~g} / \mathrm{l}$ or yield $79 \%$ to $81 \%$. No effect after addition concentration of yeast extract above $15 \%$, and the highest yield was achieved if the substrate supplemented $15 \mathrm{~g} / \mathrm{l}$ of yeast extract as nitrogen source (Table 4). However the high cost of yeast extract has a negative impact on the economics of its use in industrial scale. Similar with all Researcher have reported that the highest production of lactic acid were found with addition of 5-15 g/l of yeast extract (Hujanen and Linko, 1996); Arasaratnam,et al.,1996; Lund et al., 1992).

However the high cost of yeast extract has a negative impact on the economics of its use in industrial scale.

\section{CONCLUSIONS}

The chemical composition of the pineapple waste appears to be a good nutrient for cultivation of lactic acid bacteria. It can potentially be used as carbon source for lactic acid fermentation. The highest yield was $85.65 \%$ achieved at $40^{\circ} \mathrm{C}, \mathrm{pH}$ of $6.00,52.5 \mathrm{~g} / \mathrm{l}$ sugar concentration with $5 \mathrm{~g} / \mathrm{l}$ yeast extract.

\section{REFERENCES}

1. Arasaratnam, V., Senthuran, A and Bala subramanian. (1996). Supplementation of Whey with Glucose and different nitrogen sources for Lactic Acid Production by $\mathbf{L}$. delbrueckii. Enzyme Microb. Technology. 19(15). pp: 482-486.

2. Bardiya, N. Somayaji, D. and Khanna, N. (1996). Biomethanation of Banana Peel and Pineapple Waste.

Bioresource

Technology. 58: pp 73-76.

3. Buchta, K. (1983). Lactic Acid. In Biotechnology. ed. Rehm, H.J. VCH Verlag Weinheim. Germany. 3: pp 409-417.

4. Buckle, K.A. (1989). Biotechnology Opportunities in Waste Treatment and Utilisation for The Food Industry. In Biotechnology and The Food Industry, Ed. Rogers P.L. Breach Science Publishers. New York. pp: 261-277.

5. Busairi, A.M. and Mat, H.B. (1998). Pencirian Bahan Sisa Nanas Tempatan. Dalam Simposium Kimia Analisis ke Sebelas, Universiti Technologi Malaysia.

6. Goksungur, Y. and Guvenc, U. (1997). Batch and Continuous Production of Lactic acid from Beet Molasses by Lactobacillus delbrtueckii._J. Chem. Tech. Biotechnology (69): 399-404

7. Hujanen, H. and Y.Y, Linko, Y.Y. (1996). Effect of Temperature and Various Nitrogen Sources on Lactic Acid Production by Lactobacillus caseii. Microbiol Biotechnol. 45: pp 307-313.

8. Kroyer, G.T. (1991). Food Processing Wastes. In Bioconversion of Waste Material to Industrial Product. Ed. Martin, A.M. Elviser Applied Science London. pp:293-303.

9. Lazaro, M.J. (1989). Liquid Chromatographic Determination of Acid and Sugar in Homolactic Cucumbar Fermentation. Journal AOAC. 72(1): pp 5255.

10. Lund, B., Norddahl, B and Ahring, B. (1992). Production of Lactic Acid from Whey Using Hydrolysed Whey Protein as Nitrogen Source. Biotechnology Letters. 14(9): pp 851-856.

11. Mercier , P. and Yerushalmi,L. (1992). Kinetics of Lactic Acid Fermentation on Glucose and Corn by L. amylophilus. J. Chem Tech. Biotechnology . 55 : pp 111 121.

12. Sakamoto,M. and Komagata, K. (1996). Aerobic Growth of An Activities of NADH Oxydase and NADH Peroxidase in Lactic Acid Bacteria. J. Fermentation and Bioengineering. 29: pp $591-602$.

13. Sasaki, K., Noparatnaraphorn, N. and Nagai. S. (1991).Use of Photosynthetic Bacteria for The Production of SCP and Chemicals from Agro Industrial Waste. In Bioconversion of Waste Material to Industrial Product. Ed. Martin. A.M. Elviser Applied Science. London. pp 225-233.

14. Vahvaselha, M.I. and Linko, P. (1987). Lactic Acid Fermentation in Milk Ultrafiltrate by L. Helviticus. In Abstract of Fourth 
European Congress on Biotechnology (3): pp $317-320$
15. Vimal, O.P. and Adsole, P.G. (1976). Utilisation of Fruit and Vegetables Waste. In Research and Industry. 21(1): pp 1-7. 